\title{
Nearly Isogenic Cucumber Genotypes Differing in Leaf Size and Plant Habit Exhibit Differential Response to Water Stress
}

\author{
Sedat Serce, ${ }^{1}$ John P. Navazio, ${ }^{1}$ Ali F. Gokce, ${ }^{1}$ and Jack E. Staub ${ }^{2}$ \\ Vegetable Crops Research Unit, U.S. Department of Agriculture, Agricultural Research Service, \\ Department of Horticulture, University of Wisconsin, Madison, WI 53706
}

AdDitional INDEX wORDs. Cucumis sativus, stomatal conductance, environmental stress, drought, soil moisture tension

\begin{abstract}
Four nearly isogenic cucumber lines (Cucumis sativus L.) differing in leaf size [standard leaf $(L L)$ vs. little leaf $(l l)$ ] and plant habit [indeterminate $(\mathrm{DeDe})$ vs. determinate (dede)] were compared for their response to high soil moisture tensions in 1990 and 1996. Comparisons were made between lines for aboveground vegetative and fruit response, between two irrigation regimes, and among three postharvest treatments. Differences in vegetative plant response between lines were documented by wilting ratings, plant dry weight, fruit number and fresh weight, and fruit quality [i.e., fruit shape, seed size, seed cavity size, and pillowy fruit disorder (PFD)] ratings depending upon the stress environment. Postharvest treatment affected the quality of fruit recovered from plants subjected to water stress. Exposure of fruit at $15{ }^{\circ} \mathrm{C}$ and $85 \%$ relative humidity (RH) for 4 days after hydrocooling, resulted in lower PFD than storage of fruit at $26{ }^{\circ} \mathrm{C}$ and $60 \%$ RH for 2 days without hydrocooling. Cucumber genotypes showed differential response to water stress indicating that plant habit and leaf size can be important genetic determinants of plant response to water stress. Although plant productivity was not affected by water stress, PFD, shape, seed size, and seed cavity size of fruit from lldede plants were more severely affected by water stress than its $l l D e D e$ counterpart. Plants homozygous $l l$, in either a determinate or indeterminate background, were less susceptible to wilting under water stress conditions than their normal leaf $(L L)$ counterparts. However, plant dry weight and fruit number and weight were higher in $L L D e D e$ plants when compared to their IlDeDe counterparts. Fruit recovered from $L L D e D e$ plants were of higher quality than those recovered from $l l D e D e$ plants. Thus, wilting response to water stress is not necessarily indicative of a cucumber plant's tolerance to water stress in the reproductive stage.
\end{abstract}

Environmental stresses have a profound effect on the distribution of natural and cultivated vegetation. In many regions of the world, potentially arable land is not cultivated because of insufficient water, temperature extremes, excessive salinity or physically unfavorable soil conditions (Kramer, 1983). The most prevalent environmental stress affecting plants is lack of water (Boyer, 1985; Miller, 1986).

Plant water stress is manifested by alternations in metabolic and physiological processes (Kramer, 1983). Based on severity and duration, water stress often reduces plant vegetative and reproductive growth, photosynthesis, respiration, ion uptake, and translocation, and may render a plant more susceptible to insect and disease damage.

Plant growth and fruit yield of cucumber are significantly affected by plant exposure to soil water deficits (Janoudi et al., 1993; Navazio and Staub, 1994). Water stress can also diminish cucumber fruit quality at harvest and during postharvest storage. For example, the frequency and severity of pillowy fruit disorder (PFD) in cucumber are influenced by plant water stress and postharvest storage (Staub and Navazio, 1993; Thomas and Staub, 1992). This Ca-related anomaly appears as brown watersoaked lesions in processing cucumbers which is positively correlated with lack of overall fruit quality (Staub et al., 1988; Thomas and Staub, 1992). PFD severity in processed fruit has

Received for publication 27 Mar. 1998. Accepted for publication 1 Mar. 1999 Mention of a trade name, proprietary product, or specific equipment does not constitute a guarantee or warranty by the U.S. Department of Agriculture and does not imply its approval to exclusion of other products that may be suitable. The cost of publishing this paper was defrayed in part by the payment of page charges. Under postal regulations, this paper therefore must be hereby marked advertisement solely to indicate this fact.

${ }^{1}$ Former graduate student.

${ }^{2}$ Research horticulturist and professor; to whom reprint requests should be addressed. been associated with increased temperature, lower RH, and exclusion of hydrocooling during postharvest handling (Navazio and Staub, 1994; Thomas and Staub, 1992; Walter et al., 1990). Hydrocooling has been used to minimize the severity of PFD and to help separate the effects of soil moisture deficits on fruit quality (Navazio and Staub, 1994; Thomas and Staub, 1992).

Many measurement techniques have been employed for quantification of plant response to water stress (Barrs, 1968; Kirkham, 1985; Spomer, 1985). Visual scoring of wilt and measurement of dry weight, yield, stomatal conductance, transpiration, crop temperature, and photosynthesis have all been used in cucumber with varying degrees of success (Cummins and Krecthman, 1975; Janoudi et al., 1993; Staub and Navazio 1993; Thomas and Staub, 1992). However, any one method is not consistently reliable and all require cross-checking for accuracy (Barrs, 1968; Kirkham, 1985; Spomer, 1985).

Navazio and Staub (1994) compared nine cultivars differing genetically for leaf size [standard leaf $(L L)$ vs. little leaf $(l l)$ ] for their response to soil moisture deficits. PFD severity in fruit from watered plots was less (61\% to $26 \%$ ) than in fruit from plots where water was withheld. Moreover, the severity of PFD could be significantly reduced by hydrocooling directly after harvesting. The two little leaf $(l l)$ lines examined (WI $1983 l l$ and H-19) were derived from AR 75-79 (University of Arkansas, Fayetteville). When compared to commercial hybrids with standard-sized leaves $(L L)$, response of two $l l$ lines to moisture stress differed depending on environmental conditions [i.e., year and experiment (Expt.)]. When the stress level was high, $\mathrm{H}-19$ showed no wilting, although PFD symptoms in $\mathrm{H}-19$ fruit were significantly higher than any $L L$ hybrid tested. In contrast, wilting was not detected in WI 1983 $l l$ plants subjected to water stress, and PFD symptoms were significantly less than in $L L$ hybrids tested. Thus, although a plant may not exhibit visible symptoms of stress (wilting) during period 
of water deficits, physiological responses may occur which result in poor fruit quality. Moreover, the inconsistent response of $l l$ genotype water stress over environments suggested that little leaf size may not be indicative of (i.e., directly related to) water stress tolerance in cucumber.

The hypothesis that genetic background has an effect on water stress tolerance can be tested using nearly isogenic inbred lines (NILs) differing in leaf size ( $l l$ vs. $L L)$. NILs have been used in cucumber to test genetic and physiological hypotheses where expression of a single gene is known (Staub and Peterson, 1986). NILs were developed that differ in plant habit [indeterminate $(D e D e)$ vs. determinate $($ dede)] and leaf size [standard $(L L)$ vs. little $(l l)]$. Because of their dramatic effect on plant architecture, different combinations of these genes (e.g., llDeDe vs. lldede) can be used to test the response of architecturally different phenotypes to soil moisture deficits. Since only standard sized leaf cucumber genotypes in an indeterminate background have been used in water stress experiments (Navazio and Staub, 1994; Thomas and Staub, 1992), a study was designed to determine the response of standard and little leaf (whether genotypes of differing leaf type respond differently to soil moisture deficits), and indeterminate and determinate (whether determinate and indeterminate genotypes respond differently to soil moisture deficits) NILs to water stress.

\section{Materials and Methods}

Four NILs were compared for response to soil moisture deficits in 1990 and 1996. Plants of these NILs either received adequate water during fruit enlargement (well-watered; control) or were subjected to low soil moisture levels (water-withheld; stress). During the experimental period, NILs were evaluated for plant wilting. At the end of the experiments, yield and fruit quality components were evaluated. Fruit of each genotype harvested from water treatments were held in different storage environments identical to some of those used by Navazio and Staub (1994). These fruit were then evaluated for PFD symptoms in both years. Additionally, fruit were examined for fruit shape, seed development, and seed cavity size in 1996 experiments.

Germplasm. Four NILs differing in plant habit (determinate vs. indeterminate) and leaf size (little leaf vs. normal leaf) were developed by the U.S. Department of Agriculture (USDA), Agricultural Research Service (ARS) cucumber improvement project, Madison, Wis. NILs differing in habit and leaf size (LLDeDe, LLdede, llDeDe, and lldede) were developed by self-pollination and selection. After an initial mating between the inbred lines WI 5551 (llDeDe; Staub et al., 1992) and WI 4992 (LLdede; USDA, ARS), F progenies were produced and selected to recover the standard leaf determinate $(L-$ dede $)$ and indeterminate $(L-D e-)$ phenotypes. These phenotypes were sib-mated for six generations, then self-pollinated twice to produce LLdede, lldede, and llDeDe genotypes. Sib-mated plants at $\mathrm{F}_{6}$ were selected and pollinated for two additional generations to recover homozygous $L L D e D e, L L d e d e, l l D e D e$, and lldede genotypes $\left(\mathrm{F}_{8} \mathrm{~S}_{2}\right)$. Determinate plants were $\approx 50$ to $60 \mathrm{~cm}$ in length, and leaf areas of the first fully expanded leaf in standard and miniature-sized types were between 80 to $100 \mathrm{~cm}^{2}$ and 30 to $40 \mathrm{~cm}^{2}$, respectively (Staub et al., 1992).

EXPERIMENTAL DESIGN. In each year, two experiments using NILs were conducted at the University of Wisconsin Research Station, Hancock, Wis., on a Plainfield loamy sand (Typic updisamment; mixed mesic). There were four replications in each of two experiments (Expts. 1 and 2) in 1990, and two replications in Expt. 1, and three replications in Expt. 2 in 1996.
Plants were arranged in adjacent, randomly assigned treatment plots [control (well-watered) and stress (water-withheld)] $4.0 \mathrm{~m}$ apart. Each plot was divided into four, 6.0-m rows, with end $(1 \mathrm{~m})$ and side $(8 \mathrm{~m})$ plot borders with $L L D e D e$ genotype planted. Each treatment row was divided into four segments, $1 \mathrm{~m}$ each, and the genotypes were randomized in each of the four rows. Cucumbers were planted on $1.5-\mathrm{m}$ row centers and, spaced $\approx 10 \mathrm{~cm}$ apart on a row $(66,666$ plants per hectare). Standard fertilization, spraying, and hand cultivation were practiced in all experiments.

WATER STRESS INDUCTION. Each of the experiments in 1990 and 1996 were conducted simultaneously under similar experimental conditions (i.e., planted no more than $5 \mathrm{~d}$ apart). Control treatments (well-watered) received a minimum of $2.5 \mathrm{~cm}$ of water per week such that soil moisture tensions in any one replication did not exceed $28 \mathrm{kPa}$. In water-withheld treatments, decline of soil moisture levels was monitored and the relative loss of soil moisture was estimated by regression analysis. Soil moisture tension was monitored daily during the experiment period using tensiometers (Model 112, Irrometer Co., Riverside, Calif.), which were randomly placed in three rows in each stress treatment plot and in one row of each control treatment plot at a depth of $23 \mathrm{~cm}$. Five randomly sampled soil cores from each plot were weighed, and then dried at $110{ }^{\circ} \mathrm{C}$ for $24 \mathrm{~h}$ in 1996 . Subsequently, cores were reweighed, and percent soil water content was calculated as soil water content $=($ wet weight - dry weight $) /$ wet weight $\times 100$.

Moisture was supplied through a zoned, drip irrigation system to supplement natural precipitation. Drip lines were uniformly placed $4 \mathrm{~cm}$ from the bases of plants and at a $4 \mathrm{~cm}$ depth from the soil surface. All water treatment plots (control vs. stress) received the same amount of water until the experiments were initiated.

Movable, rain-out shelters were used to prevent stress treatments from receiving ambient precipitation during the stress episodes. Treatments were planted $1 \mathrm{~m}$ from the edge of the shelters. Treatment plots were harvested once and then fruit $>4$ $\mathrm{cm}$ in length were removed at the initiation of the stress episode to ensure synchronization of fruiting between genotypes and across treatments. Thus, a stress episode in water-withheld plots began after removal of fruit and the termination of irrigation.

IDENTIFICATION OF GENOTYPIC EFFECTS. Daily visual wilt ratings were taken between 1300 and 1500 HR during the stress episode based on a six point scale according to Navazio and Staub (1994), where $0=$ fully turgid plant; $1=$ loss of turgor resulting in recurved margins of leaves (leaf margins cupped inward) between base of plant and midvine; 2 = leaves between base of plant and mid vine undulating and recurved; $3=\approx 50 \%$ wilting of leaves from base of plant to mid vine; $4=\approx 75 \%$ of plant wilted from base to terminal whorl, and $5=$ complete wilting of leaves $(100 \%)$ from base to terminal whorl. The average degree of wilt for the entire stress period was calculated and experiments were terminated 24 $\mathrm{h}$ after at least one line in the water-withheld plots demonstrated a consistent wilt rating of ' 5 ' in all replications (maximum of 10 d, 1996). Fruit number and fruit fresh weight per plant were recorded. For plant dry weight determinations all plants (without fruit) in experiments were harvested and dried at $60{ }^{\circ} \mathrm{C}$ for $72 \mathrm{~h}$. Cucumber flowers abort and fruit are reabsorbed under biotic and abiotic stresses. Thus, evaluation of stress treatments (waterwithheld and control) for fruit number per plant reflects decrease in yield due to abortion/reabsorption.

Postharvest StORage Experiments. Harvested fruit were subjected to three postharvest (PH) regimes in 1990 and two in 1996 to assist in differentiating stress treatment according to Navazio and Staub (1994). Fruit [3.2 to $3.5 \mathrm{~cm}$ in diameter (U.S. Grade, 2B-3A)] of each genotype within each treatment were 
randomly partitioned into either three (1990) or two (1996) groups, and held at $\approx 25^{\circ} \mathrm{C}$ and $60 \% \mathrm{RH}$. Within $3 \mathrm{~h}$ after harvest, fruit from each treatment were placed in differing conditions of temperature, relative humidity, and storage duration ( 2 to $4 \mathrm{~d}$ ) in controlled environments. Fruit were subjected to either of the following treatments: 1) $4 \mathrm{~d}$ storage at $15{ }^{\circ} \mathrm{C}, 85 \% \mathrm{RH}$ [vapor pressure deficit $(\mathrm{VPD})=0.249 \mathrm{kPa}](\mathrm{PH} 1$; cool temperature and high humidity); 2) hydrocooling to $8{ }^{\circ} \mathrm{C}$ within $60 \mathrm{~min}$ of harvest and storage at $15{ }^{\circ} \mathrm{C}, 85 \% \mathrm{RH}(\mathrm{VPD}=0.249 \mathrm{kPa})$ for $4 \mathrm{~d}(\mathrm{PH} 2$; hydrocooling, cool temperature and high humidity), and 3) $2 \mathrm{~d}$ storage at $26{ }^{\circ} \mathrm{C}, 60 \% \mathrm{RH}(\mathrm{VPD}=1.298 \mathrm{kPa})(\mathrm{PH} 3$; ambient conditions). There were at least 10 fruit in each experimental unit in each experiment (experimental unit $=$ sample with each postharvest treatment for each genotype across stress treatments). Because of results of 1990 experiments and those of Navazio and Staub (1994), only PH 2 and PH 3 regimes were employed in 1996 to evaluate effects of hydrocooling on the fruit quality of NILs.

Fruit were hydrocooled and cooling trends were modeled according to Navazio and Staub (1994) after considerations made by Holman (1990). The cooling trend during hydrocooling was modeled using Newton's law of cooling: In (fruit temperature water temperature $)=a+b \times$ time using linear regression $(a$ and $\mathrm{b}$ are constants estimated from each data set). Cooling response (y) was calculated as $\mathrm{y}=10.6-0.2 \times$ time $\left(R^{2}=0.76\right)$, and $\mathrm{y}=$ $22.181-0.397 \times$ time $\left(R^{2}=0.90\right)$ in 1990 and 1996 , respectively. Fruit temperature was calculated using thermocouples $(0.502 \mathrm{~mm}$ in diameter) inserted into the midsection of fruit 1.5 to $2 \mathrm{~cm}$ below the epidermis. After postharvest storage, all fruit were fresh-pack processed in brine solution supplied by Claussen Pickle Company, Woodstock, Ill.

Processed cucumbers were held 14 weeks at $8{ }^{\circ} \mathrm{C}$ before evaluation. All fruit were halved in longitudinal section, and evaluated for severity of PFD, by trained judges' evaluations. Fruit were assigned a percentage PFD value (percentage longitudinal area showing pillowed tissue) by visual approximation, and rated on a five point scale $(0=<1 \% ; 1=1 \%$ to $9 \% ; 2=10 \%$ to $20 \%$; $3=21 \%$ to $39 \% ; 4=\geq 40 \%$ PFD) according to Navazio and Staub (1994).

In the 1996 experiments, samples used in PFD evaluations were also evaluated for fruit shape, seed development, and seed cavity size using a 1 to 4 point scale. For shape, fruit were rated as 1 = commercially acceptable (cylindrical), $2=$ generally cylindrical but having some blossom-end taper (commercially undesirable), 3 = not cylindrical with considerable blossom-end taper (commercially undesirable and largely unacceptable), and 4 $=$ not cylindrical with constrictions and/or curvature (commercially unacceptable). Seed size was estimated by visual approximation as, $1=$ small seed size (embryo without enlargement) $=\leq$ $2 \mathrm{~mm}$ in length, $2=$ size $>2 \leq 4 \mathrm{~mm}, 3=$ size (commercially undesirable) $>4 \leq 8 \mathrm{~mm}$, and $4=$ size (commercially unacceptable) $=>8 \mathrm{~mm}$. Likewise, seed cavity size (relative diameter of the exocarp) was estimated as $1=$ small cavity size (commercially unacceptable) $=\leq 12 \mathrm{~mm}, 2=$ size $>12 \leq 18 \mathrm{~mm}$ (commercially undesirable), $3=$ size $>18 \leq 21 \mathrm{~mm}$, and $4=$ size $=>21 \mathrm{~mm}$. These variables are useful for estimating fruit quality because fruit shape is a factor in processed product determination (e.g., long thin cucumbers are packaged as cut spears), seed size is an indicator of seed maturity [large seeds indicate rapid fruit enlargement (Navazio and Staub, 1994; Thomas and Staub, 1992)] stress during fruit enlargement, and seed cavity size is an indicator of fruit growth rate and processed product quality (i.e., a combination of small exocarp and reduced length to diameter ratio are indicative of reduced fruit growth rate).
Statistical analysis. Analyses of variance (ANOVA) were performed for each variable examined to determine experiment and treatment differences. Mean separations were performed with Fisher's protected LSD at $P=0.05$ (Steel and Torrie, 1980). In order to determine the effect of genetic background, comparisons were performed for plant habit (llDeDe vs. lldede) and leaf size (LLdede vs. lldede) (Serce, 1997). A split-split-plot analysis was used to evaluate plant wilt ratings. The whole-plot, split-plot, and splitsplit-plot factors were water treatments, genotypes, and days, respectively. Likewise, a split-plot analysis was employed to evaluate plant measurement data (i.e., fruit number per plant, average fruit weight, plant dry weight). The whole-plot, and splitplot factors were water treatments, and genotypes, respectively. ANOVA and mean separations of evaluations for postharvest fruit quality variables (pillowy, fruit shape, seed development, and seed cavity size) were performed separately for each group of judges using a split-split-split-plot analysis. The whole-plot and split-plot factors were water stress and genotype, respectively, with the sub-subplot factor of postharvest treatment nested within genotype, and the sub-sub-subplot factor of judges nested within postharvest treatment.

Regression analysis was used to evaluate soil water content data using days as independent variables and soil moisture tension or soil water content values as dependent variables to compare water stress treatments (stress vs. control) according to Navazio and Staub (1994). Analyses of variance were also utilized with a split-plot analysis, where the whole-plot, and split-plot factors were water treatments, and days, respectively.

\section{Results}

Soil moisture tension (SMT) and plant measurements supported visual wilt observations in each experiment. In 1990 and 1996, regression slope estimates of SMT values ( $b_{1}$ values; Table 1) indicated there were significant differences in soil moisture status between treatments after water was withheld. With elevated SMT conditions, yield was reduced and fruit quality components were adversely affected (i.e., higher PFD ratings and lower fruit quality ratings).

Regression slope estimates of SMT values ( $b_{1}$ values $)$ indicate there were significant differences in soil moisture status between irrigation treatments during a depletion cycle (Table 1). Soil moisture depletion rates were similar in all water-withheld plots within and between experiments within a year (Serce, 1997). The mean of the SMT in control plots over both years was relatively low; $16.3 \mathrm{kPa}$ in 1990 and $10.1 \mathrm{kPa}$ in 1996 . In contrast, plots from which water was withheld showed significant increases in SMT ( $b_{1}$ values) over time in all experiments. Although it required more time $(10 \mathrm{~d})$ to reach wilting in 1996 compared to 1990 (7 d), the highest mean SMT levels in water-withheld plots for all experiments ranged from 67.7 to $71.1 \mathrm{kPa}$. Daily mean SMT in waterwithheld plots increased an average of $11.7 \mathrm{kPa} \cdot \mathrm{d}^{-1}$ across replications in 1990 and $5.2 \mathrm{kPa} \cdot \mathrm{d}^{-1}$ in 1996 . The well-watered plots increased an average of $0.6 \mathrm{kPa} \cdot \mathrm{d}^{-1}$ in 1990 and $1.0 \mathrm{kPa} \cdot \mathrm{d}^{-1}$ in 1996. Slope inequality between control and water-withheld treatments for each experiment indicated significant differences in soil moisture depletion rates. Differences between water treatments were also detected by examination of soil cores. ANOVA and regression analysis modeling of well-watered $[\mathrm{y}=-0.101 \mathrm{x}+$ 6.672 for well-watered $\left.\left(r^{2}=0.14\right)\right]$ and water-withheld $[\mathrm{y}=-$ $\left.0.071+4.063\left(r^{2}=0.14\right)\right]$ indicated that plants in water-withheld plots had been subjected to water stress. Daily differences in soil moisture content and a two-way, day $\times$ water treatment level 
Table 1. Estimates of soil moisture tension $(\mathrm{kPa})$ during cucumber water stress experiments.

\begin{tabular}{|c|c|c|c|c|c|c|c|c|c|c|c|c|c|c|c|}
\hline \multirow[b]{2}{*}{ Treatment } & \multicolumn{12}{|c|}{ Treatment days } & \multicolumn{3}{|c|}{ Regression estimates } \\
\hline & 1 & 2 & 3 & 4 & 5 & 6 & 7 & 8 & 9 & 10 & $\bar{X}$ & SE & $\mathrm{b}_{1}$ & SE & $R^{2}$ \\
\hline$\overline{1990^{z}}$ & & & & & & & & & & & & & & & \\
\hline Watered $^{\mathrm{y}}$ & 12.8 & 12.4 & 17.3 & 24.5 & 15.4 & 12.9 & 18.4 & --- & --- & --- & 16.3 & 4.3 & 0.6 & 1.0 & 0.05 \\
\hline $\begin{array}{l}\text { Water withheld } \\
1996^{x}\end{array}$ & 5.5 & 9.9 & 13.7 & 43.0 & 55.3 & 59.7 & 67.7 & --- & --- & --- & 36.4 & 26.1 & $11.7^{* * * *}$ & 1.4 & 0.93 \\
\hline Watered & 4.8 & 8.4 & 9.6 & 9.6 & 4.8 & 8.0 & 11.6 & 14.4 & 15.2 & 14.8 & 10.1 & 3.8 & 1.0 & 2.6 & 0.66 \\
\hline Water withheld & 22.0 & 26.0 & 30.8 & 33.2 & 33.7 & 38.4 & 44.7 & 52.5 & 63.1 & 71.1 & 41.6 & 16.1 & $5.2^{* * * *}$ & 4.1 & 0.93 \\
\hline
\end{tabular}

${ }^{\mathrm{z} C o m b i n e d ~ m e a n s ~ o f ~ t w o ~ e x p e r i m e n t s ~ h a v i n g ~ t w o ~ t e n s i o m e t e r s ~ p l a c e d ~ i n ~ e a c h ~ o f ~ f o u r ~ r e p l i c a t i o n s . ~}$

${ }^{y}$ Water stress treatments when control (watered) equals sufficient soil moisture for growth and development, and stress (water withheld) equals soil moisture deficits to cause wilting $(\approx 55 \mathrm{kPa})$ during second harvest fruit enlargement.

${ }^{x}$ Combined means of two experiments having one tensiometer in control and three tensiometers on stress plots placed in each of two or three replications.

${ }^{* * *}$ Significant at $P \leq 0.001$.

interaction were detected $(P=0.001 ; P=0.001)$. Mean percent soil water content for well-watered and water-withheld treatments were $6.11 \%$ and $3.67 \%$, respectively (Serce, 1997).

No plants of any genotype in well-watered treatments exhibited wilting. In contrast, wilt response of genotypes differed in water-withheld treatments. Because LLDeDe and LLdede genotypes were not synchronized (flowered and fruited earlier than the rest of the genotypes) with the other genotypes for fruit enlargement stage during stress episode in 1990 and 1996, respectively, those genotypes were not included in the analyses. The main effect of water treatments and water treatments $\times$ genotype interaction were highly significant $(P=0.001)$. In each experiment in 1990 and 1996, wilt ratings were higher in $L L$ plants than in their $l l$ counterparts, which were themselves similar (Table 2).

The main effects of water stress treatments on plant productivity $(P=0.001)$, and fruit quality in both 1990 and 1996 were significant. Genotype $\times$ environment interactions were also observed for plant productivity variables $(P \leq 0.01)$. Genotypic differences and second order genotype $\times$ water treatment interactions were highly significant for all plant productivity measurements $(P=0.001)$ suggesting that genotypes responded to water stress treatments differently.

Water stress adversely affected fruit quality (Tables 3 and 4). Water treatment main effects were significant for all variables evaluated. Significant water treatment $\times$ genotype interactions were obtained for PFD and seed cavity size evaluations (Serce, 1997). The main effects of postharvest (PH) treatment were significant for PFD, while, fruit shape, seed development, and seed cavity size differences among PH treatments were not detected (Serce, 1997).

In all experiments, fruit subjected to $\mathrm{PH} 3$ had the lowest fruit quality (Tables 3 and 4 ). Genotype $\times$ postharvest treatment interactions were detected (Serce, 1997). Judge, postharvest treatment and genotype main effects for PFD were significant $(P \leq$ 0.05 ) depending upon the experiment (Table 3; judge data not presented). Judge ratings differed between years but rankings were similar between experiments within a year.

1990 EXPERIMENTs. Mean fruit number per plant for wellwatered and water-withheld treatments across experiments were 2.42 and 2.16 (Expt. 1) and 2.29 and 1.87 (Expt. 2) (Table 5). Mean fruit number of lldede and LLdede plants were similar, and higher than that recovered from $l l D e D e$ plants in well-watered treatments in Expt. 1. In contrast, mean fruit number recovered from lldede and llDeDe in well-watered treatments in Expt. 2 were similar, but greater than mean fruit number produced by LLdede plants. While there were no differences detected in the production of fruit among NILs in the water-withheld treatment in Expt. 1, fruit number recovered from lldede plants in Expt. 2 was higher than from $l l D e D e$ and LLdede plants, which were similar.

Mean fresh weight of fruit recovered from well-watered and water-withheld treatments were $271.2 \mathrm{~g}$ and $259.2 \mathrm{~g}$, and 248.4 $\mathrm{g}$ and $254.7 \mathrm{~g}$ in Expts. 1 and 2, respectively (Table 5). Fruit harvested from LLdede plants in Expt. 1 and 2 in well-watered treatments weighed less than fruit from lldede and $l l D e D e$ plants. While fruit weight of $l l D e D e$ plants in Expt. 1 were, on average, heavier than fruit harvested from lldede plants in the well-watered treatment in Expt. 1, fruit weight of these two NILs was similar in Expt. 2. In water-withheld treatments, fruit fresh weight of $L L d e d e$ plants was lower than $l l D e D e$ plants in both experiments, but was

Table 2. Degree of wilting in nearly isogenic cucumber lines exposed to soil water deficits.

\begin{tabular}{|c|c|c|c|c|}
\hline \multirow[b]{2}{*}{ Nearly isogenic line ${ }^{y}$} & \multirow{2}{*}{$\begin{array}{c}\text { Duration of } \\
\text { treatment } \\
\text { (d) }\end{array}$} & \multirow{2}{*}{$\begin{array}{c}\text { No. of days } \\
\text { plants } \\
\text { were wilted }\end{array}$} & \multicolumn{2}{|c|}{$\begin{array}{c}\text { Mean wilt } \\
\text { rating }^{z}\end{array}$} \\
\hline & & & $\overline{\mathrm{X}}$ & SE \\
\hline \multicolumn{5}{|l|}{$\overline{1990^{\mathrm{w}}}$} \\
\hline \multicolumn{5}{|l|}{ Experiment 1} \\
\hline lldede & 7 & 1 of 7 & 0.50 & 0.29 \\
\hline llDeDe & 7 & 1 of 7 & 0.75 & 0.25 \\
\hline LLdede & 7 & 2 of 7 & 1.25 & 0.16 \\
\hline \multicolumn{5}{|l|}{ Experiment 2} \\
\hline lldede & 7 & 2 of 7 & 0.75 & 0.25 \\
\hline$l l D e D e$ & 7 & 2 of 7 & 0.88 & 0.23 \\
\hline LLdede & 7 & 3 of 7 & 2.45 & 0.54 \\
\hline \multicolumn{5}{|l|}{$1996^{\mathrm{u}}$} \\
\hline \multicolumn{5}{|l|}{ Experiment 1} \\
\hline lldede & 10 & 2 of 10 & 0.26 & 0.10 \\
\hline llDeDe & 10 & 2 of 10 & 0.29 & 0.12 \\
\hline$L L D e D e$ & 10 & 6 of 10 & 1.61 & 0.32 \\
\hline \multicolumn{5}{|l|}{ Experiment 2} \\
\hline lldede & 10 & 2 of 10 & 0.26 & 0.41 \\
\hline llDeDe & 10 & 2 of 10 & 0.33 & 0.17 \\
\hline$L L D e D e$ & 10 & 6 of 10 & 1.65 & 0.14 \\
\hline
\end{tabular}

$\overline{{ }^{\mathrm{z}} \text { Wilt ratings were made daily on a scale of } 0 \text { to } 5 \text {, where } 0=\text { fully turgid }}$ plants and $5=$ complete wilt of leaves.

${ }^{y} L L=$ normal size leaf, $l l=$ little leaf, dede $=$ determinate, and $D e D e=$ indeterminate.

${ }^{\mathrm{x}}$ Stress treatment consisted of withholding soil moisture to cause wilting during fruit enlargement.

${ }^{\mathrm{w}}$ Mean of four replications.

uMean of two replicatons in Expt. 1 and three replications in Expt. 2. 
Table 3. Mean pillowy fruit disorder (PFD) ratings of processed fruit of nearly isogenic cucumber lines subjected to water stress and several postharvest treatments.

\begin{tabular}{|c|c|c|c|c|}
\hline \multirow[b]{3}{*}{ Treatment } & \multicolumn{4}{|c|}{ PFD rating $^{z}$} \\
\hline & \multicolumn{2}{|c|}{$\begin{array}{c}1990 \\
\text { Experiment }^{\mathrm{y}}\end{array}$} & \multicolumn{2}{|c|}{$\begin{array}{c}1996 \\
\text { Experiment }^{\mathrm{x}}\end{array}$} \\
\hline & 1 & 2 & 1 & 2 \\
\hline \multicolumn{5}{|l|}{ Stress level $^{\mathrm{w}}$} \\
\hline Watered & 0.88 & 0.79 & 2.21 & \\
\hline Water witheld & 1.04 & 1.02 & 2.40 & 2 \\
\hline $\operatorname{LSD}_{(0.05)}$ & 0.11 & 0.14 & 0.10 & 0 . \\
\hline \multicolumn{5}{|c|}{ Nearly isogenic line ${ }^{v}$} \\
\hline lldede & 0.99 & 0.88 & 2.66 & \\
\hline LLdede & 0.73 & 0.85 & --- & \\
\hline llDeDe & 1.16 & 0.99 & 2.47 & \\
\hline LLDeDe & --- & --- & 1.78 & 1 \\
\hline $\operatorname{LSD}_{(0.05)}$ & 0.15 & 0.11 & 0.19 & 0 \\
\hline \multicolumn{5}{|l|}{ Postharvest $^{\mathrm{u}}$} \\
\hline PH 1 & 0.73 & 0.55 & --- & \\
\hline PH 2 & 0.86 & 0.90 & 2.03 & \\
\hline PH 3 & 1.29 & 1.27 & 2.58 & \\
\hline $\operatorname{LSD}_{(0.05)}$ & 0.15 & 0.11 & 0.03 & \\
\hline
\end{tabular}

zPFD rating: $0=<1 \% ; 1=1 \%$ to $9 \%$ PFD; $2=10 \%$ to $20 \%$ PFD; $3=21 \%$ to $39 \%$ PFD; and $4=\geq 40 \%$ PFD.

${ }^{\mathrm{y}}$ Mean of four replications.

${ }^{\mathrm{x}}$ Mean of two replications in Expt. 1 and three replications in Expt. 2.

${ }^{w}$ Water stress treatments when control equals sufficient solid moisture for growth and development and stress equals soil moisture withheld to cause wilting during second harvest fruit enlargement.

${ }^{\mathrm{v}} L L=$ normal size leaf, $l l=$ little leaf, dede $=$ determinate, and $D e D e=$ indeterminate.

${ }^{\mathrm{u}} 1=4 \mathrm{~d}$ storage at $15^{\circ} \mathrm{C}, 85 \% \mathrm{RH} ; 2=$ hydrocooling to $\approx 8^{\circ} \mathrm{C}$ within $1 \mathrm{~h}$ and storage at $15{ }^{\circ} \mathrm{C}, 85 \% \mathrm{RH}$ for $4 \mathrm{~d}$; and $3=2 \mathrm{~d}$ storage at $26^{\circ} \mathrm{C}, 60 \% \mathrm{RH}$. similar to fruit obtained from lldede plants in Expt. 1. In contrast, fruit of lldede in the water-withheld treatment in Expt. 2 were, on average, heavier than fruit harvested from LLdede plants.

Mean dry weight of plants in the well-watered and waterwithheld treatments were 35.5 and $40.4 \mathrm{~g}$, and 28.7 and $21.6 \mathrm{~g}$ in Expts. 1 and 2, respectively (Table 5). Plants genotypically LLdede in each experiment in either well-watered and waterwithheld treatments were smaller than its isogenic counterparts. While the dry weight of $l l D e D e$ plants was more than lldede plants in Expt. 1 in the well-watered treatment, $l l D e D e$ plants weighed, on average, less than lldede plants examined in Expt. 2 in the wellwatered treatment. In contrast, dry weight of $l l D e D e$ plants was less than lldede plants in Expt. 1 in the water-withheld treatment, and there was no difference detected in dry weight between lldede and $L L D e D e$ genotypes in Expt. 2 in the water-withheld treatment.

Mean PFD ratings were higher in fruit harvested from waterwithheld treatments when compared to those obtained from wellwatered treatments indicating that water stress affected fruit quality (Table 3 ). The PFD ratings of fruit harvested from $l l D e D e$ plants were higher than those of its nearly isogenic counterparts (lldede, LLdede) in both 1990 experiments. In Expt. 1, lldede fruit were given significantly higher PFD ratings than LLdede fruit.

1996 EXPERIMENTS. Response of genotypes in well-watered and water-withheld treatments was similar for each measurement of productivity (Table 5). Mean fruit number per plant for wellwatered and water-withheld treatments were 3.24 and 3.56, and 1.95 and 1.92 in Expts. 1. and 2, respectively. The LLDeDe genotype was higher yielding in either well-watered or waterwithheld treatments when compared to its llDeDe and lldede counterparts. While fruit number of the $l l D e D e$ line was less than lldede in either well-watered or water-withheld treatments in Expt. 1, mean number of fruit recovered from these genotypes was similar in Expt. 2.

Table 4. Mean fruit quality responses of nearly isogenic cucumber lines subjected to water stress experiments in 1996.

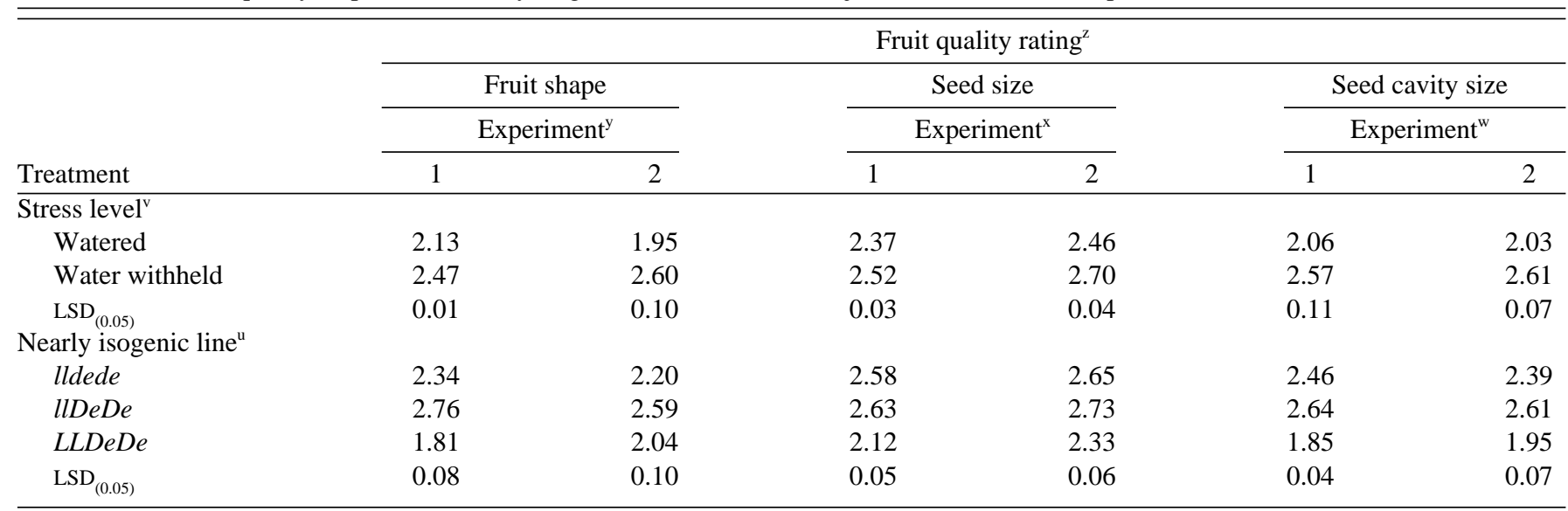

${ }^{\mathrm{z}}$ Fruit shape is given as $1=$ commercially acceptable (cylindrical), $2=$ generally cylindrical but having some blossom-end taper (commercially undesirable), $3=$ not cylindrical with considerable blossom-end taper (commercially undesirable and largely unacceptable), and $4=$ not cylindrical with restrictions and/or curvature (commercially unacceptable). Seed size as, $1=$ small seed size (embryo without enlargement) $=\leq 2 \mathrm{~mm}$ in length, $2=$ size $>2 \leq 4 \mathrm{~mm}, 3=$ size (commercially undesirable) $>4 \leq 8 \mathrm{~mm}$, and $4=$ size (commercially unacceptable) $=>8 \mathrm{~mm}$, and seed cavity size (relative diameter of the exocarp) estimated as $1=$ small cavity size (commercially unacceptable) $=\leq 12 \mathrm{~mm}, 2=$ size $>12 \leq 18 \mathrm{~mm}$ (commercially undesirable), $3=$ size $>18 \leq 21 \mathrm{~mm}$, and $4=$ size $=>21 \mathrm{~mm}$.

y Mean of two replications in Expt. 1 and three replications in Expt. 2.

${ }^{\mathrm{x}}$ Mean of two replications in Expt. 1 and three replications in Expt. 2.

${ }^{w}$ Mean of two replications in Expt. 1 and three replications in Expt. 2.

${ }^{v}$ Water stress treatments when control equals sufficient soil moisture for growth and development and stress equals soil moisture withheld to cause wilting during second harvest fruit enlargement.

${ }^{\mathrm{u}} L L=$ normal size leaf, $l l=$ little leaf size, $d e d e=$ determinate, and $D e D e=$ indeterminate. 
Table 5. Mean response of nearly isogenic cucumber lines exposed to soil water stress experiments.

\begin{tabular}{|c|c|c|c|c|c|c|}
\hline \multirow[b]{3}{*}{$\begin{array}{l}\text { Nearly } \\
\text { isogenic } \\
\text { line }^{x}\end{array}$} & \multicolumn{6}{|c|}{ Response } \\
\hline & \multicolumn{3}{|c|}{ Experiment $1^{z}$} & \multicolumn{3}{|c|}{ Experiment $2^{y}$} \\
\hline & $\begin{array}{l}\text { Fruit/ } \\
\text { plant } \\
\text { (no.) }\end{array}$ & $\begin{array}{l}\text { Fruit } \\
\text { fresh wt/ } \\
\text { plant } \\
(\mathrm{g})\end{array}$ & $\begin{array}{c}\text { Dry wt/ } \\
\text { plant } \\
(\mathrm{g})\end{array}$ & $\begin{array}{l}\text { Fruit/ } \\
\text { plant } \\
\text { (no.) }\end{array}$ & $\begin{array}{c}\text { Fruit } \\
\text { fresh wt/ } \\
\text { plant } \\
(\mathrm{g})\end{array}$ & $\begin{array}{c}\text { Dry wt/ } \\
\text { plant } \\
(\mathrm{g})\end{array}$ \\
\hline \multicolumn{7}{|l|}{1990} \\
\hline \multicolumn{7}{|l|}{ Watered } \\
\hline lldede & 2.71 & 250.2 & 45.7 & 2.61 & 297.2 & 51.4 \\
\hline llDeDe & 1.86 & 390.5 & 39.4 & 2.25 & 263.7 & 42.8 \\
\hline LLdede & 2.71 & 172.8 & 21.4 & 1.65 & 184.3 & 27.0 \\
\hline Mean & 2.42 & 271.2 & 35.5 & 2.17 & 248.4 & 40.4 \\
\hline \multicolumn{7}{|c|}{ Water withheld } \\
\hline lldede & 2.59 & 276.3 & 36.6 & 2.41 & 287.7 & 38.4 \\
\hline llDeDe & 2.30 & 302.9 & 30.9 & 1.73 & 305.9 & 39.5 \\
\hline LLdede & 2.00 & 198.4 & 18.6 & 1.48 & 170.6 & 16.9 \\
\hline Mean & 2.29 & 259.2 & 28.7 & 1.87 & 254.7 & 31.6 \\
\hline $\operatorname{LSD}_{(0.05)}$ & 0.83 & 139.2 & 6.8 & 0.57 & 81.5 & 5.5 \\
\hline \multicolumn{7}{|l|}{1996} \\
\hline \multicolumn{7}{|l|}{ Watered } \\
\hline lldede & 2.39 & 135.0 & 21.5 & 2.60 & 196.9 & 21.8 \\
\hline llDeDe & 1.62 & 109.7 & 23.3 & 2.68 & 243.3 & 30.1 \\
\hline LLDeDe & 5.42 & 412.5 & 76.3 & 5.12 & 389.1 & 62.3 \\
\hline Mean & 3.24 & 219.1 & 40.4 & 3.56 & 276.4 & 38.1 \\
\hline \multicolumn{7}{|c|}{ Water withheld } \\
\hline lldede & 1.94 & 103.0 & 12.5 & 1.80 & 109.9 & 16.1 \\
\hline llDeDe & 1.41 & 76.4 & 12.3 & 1.50 & 97.3 & 16.5 \\
\hline LLDeDe & 2.51 & 207.7 & 27.0 & 2.46 & 161.1 & 28.6 \\
\hline Mean & 1.95 & 129.0 & 17.3 & 1.92 & 122.8 & 20.4 \\
\hline $\operatorname{LSD}_{(0.05)}$ & 0.10 & 66.3 & 2.4 & 0.36 & 32.2 & 3.5 \\
\hline
\end{tabular}

${ }^{\mathrm{z}}$ Mean of four replications in 1990 experiment, mean of two replications in 1996 experiment.

${ }^{\mathrm{y}}$ Mean of four replications in 1990 experiment, mean of three replications in 1996 experiment.

${ }^{\mathrm{x}} L L=$ normal leaf size, $l l=$ little leaf size, $d e d e=$ determinate, and $D e D e=$ indeterminate.

Mean fresh weight of fruit recovered from well-watered and water-withheld treatments were $219.1 \mathrm{~g}$ and $276.4 \mathrm{~g}$, and $129.0 \mathrm{~g}$ and $122.8 \mathrm{~g}$ in Expts. 1 2, respectively (Table 5). Highest fruit weight was realized from $L L D e D e$ plants in each experiment in either well-watered or water-withheld treatments. Although mean weight of fruit of the $l l D e D e$ line was similar or higher than the lldede line in the well-watered treatment, fruit weight of both lines was similar in the water-withheld treatment.

Mean dry weight of plants in the well-watered and waterwithheld treatments were 40.4 and $38.1 \mathrm{~g}$, and 17.3 and $20.4 \mathrm{~g}$ in Expts. 1 and 2, respectively (Table 5). Plants genotypically $L L D e D e$ in each experiment in either well-watered or waterwithheld treatments were larger than its isogenic counterparts. While dry weight of the llDeDe and lldede lines was similar in either well-watered or water-withheld treatments in Expt. 1 and the water-withheld treatment in Expt. 2, dry weight of $l l D e D e$ plants was significantly higher than lldede plants in the wellwatered treatment in Expt. 1.

Fruit harvested from genotypes in water-withheld treatments differed in PFD severity (Table 3 ). In both experiments, severity of PFD in fruit of the lldede genotype was greater than that detected in the LLdede genotype. Fruit of the LLDeDe genotype exhibited the least amount of PFD symptoms.

Comparisons among NILs for general fruit quality characteristics following water stress treatment recapitulated PFD observations (Table 4). Fruit harvested from well-watered treatments possessed higher quality when compared to those obtained from water-withheld treatments. The rank order of fruit shape, seed size, and seed cavity size ratings among NILs in water-withheld treatments in both experiments was $l l D e D e>l l d e d e>L L D e D e$. These results indicate the $l l D e D e$ line was most affected by water stress treatment and $L L D e D e$ was the least affected.

\section{Discussion}

Cucumber plants with different plant architecture were adversely affected by the low soil moisture levels imposed in these experiments (Tables 2-5). Depending on test environment and genotype, increases in wilting incidence, and decreases in plant dry weight and fruit number and weight, generally paralleled decreases in fruit quality observed in fruit recovered from water stress treatments. Higher plant wilt scores, and lower fruit number per plant average fruit weight and plant dry weight scores of stress-treated plants when compared to well-watered controls indicate that water stress affected plant productivity. Likewise, higher PFD, fruit shape, seed development, and seed cavity size scores in fruit from water stressed plants when compared to well-watered controls, indicated that exposure to soil moisture stress decreased fruit quality. However, exposure of fruit at $15{ }^{\circ} \mathrm{C}$ and $85 \% \mathrm{RH}$ for $4 \mathrm{~d}$ after hydrocooling, resulted in lower PFD than storage of fruit at $26^{\circ} \mathrm{C}$ and $60 \% \mathrm{RH}$ for $2 \mathrm{~d}$ without hydrocooling regardless of the genotype evaluated. These observations paralleled those of Thomas and Staub (1992) and Navazio and 
Staub (1994) where the frequency and severity of PFD was higher in fruit harvested from water stressed plants when compared to wellwatered controls. In contrast to the present study, direct genotypic comparisons between lines differing in leaf size $(L L$ vs. $l l)$ or plant habit (DeDe vs. dede) were not possible in the studies of Navazio and Staub (1994).

Wilting in cucumber may not always be a function of soil moisture content. For example, plant wilting frequently occurs in "fruiting" plants as a result of high vapor pressure deficits (i.e., midday wilts). Although such observations indicate that affected plants are under stress, plant turgor pressure is usually restored during late afternoon and evening hours depending on an array of environmental factors (e.g., irradiance, temperature, and RH). In our experiments, plots were harvested when a line exhibited extreme, presumably unrecoverable wilting (Table 1). Often, in days previous to harvest (usually $1 \mathrm{~d}$ ), plants were observed to wilt during the day and then recover during evening hours. The fact that differences were seen in fruiting and quality characteristics between fruit recovered from well-watered and water-withheld treatments (high soil moisture tensions) at harvest indicates that the observed disparities between these treatments were induced by low soil moisture levels.

Comparative analysis of the effect of alleles conditioning plant habit (De vs. $d e$ ) in a little leaf genetic background (i.e., lldede vs. llDeDe) indicate that although plant productivity is not affected by water stress (Table 5), fruit quality can be (Tables 3 and 4). Data show that PFD (1990 and Expt. 2, 1996), shape, seed size, and seed cavity size of fruit from $l l D e D e$ plants are more severely affected by water stress than its lldede counterpart. These results support findings of Navazio and Staub (1994) which indicated that a plant may not exhibit visible symptoms of stress (wilting) during period of water deficits (Expt. 1, 1990, and Expts. 1 and 2, 1996), but physiological responses may occur which result in poor fruit quality (Tables 3 and 4) (Serce, 1997). Moreover, genotypic differences in susceptibility to Ca-related disorders has been reported in several crops (Johnson, 1991; Li and Gabelman, 1990). Cultivar variability in response to water stress and its concomitant influence on PFD has been previously observed in cucumber (Navazio and Staub, 1994; Staub and Navazio, 1993; Staub et al., 1988).

Our study indicates that the gene conditioning leaf size can have a significant influence on the response of cucumber plants to water stress induced by soil moisture deficits. The leaf size alleles $(l$ and $L)$ were evaluated in a determinate (de) background in 1990 (lldede vs. LLdede) and an indeterminate (De) background in 1996 (llDeDe vs. $L L D e D e$ ). In 1990, the wilt rating assigned to LLdede plants was higher than its lldede counterpart (Table 2). Likewise, dry weight of LLdede plants (both experiments) and fruit number and weight (Expt. 2) were less than their lldede counterpart (Table 5). PFD frequency was significantly higher in lldede plants when compared to LLdede plants in Expt. 1 (Table 3). In 1996, wilting was more severe in LLDeDe plants than in $l l D e D e$ plants (Table 2). Plant dry weight and fruit number and weight was higher in LLDeDe plants when compared to their $l l D e D e$ counterpart (Table 5). Fruit recovered from $L L D e D e$ were of higher quality than fruit recovered from $l l D e D e$ plants (Tables 3 and 4). Plants homozygous $l l$ in either a determinate or indeterminate background were less susceptible to wilting under water stress conditions than their normal leaf $(L)$ counterparts (Table 2). In contrast, plant productivity of the normal leaf genotype was higher than their little leaf counterparts in either a determinate or indeterminate genetic background (Table 5). Fruit quality of normal leaf types in either background was generally higher than that of little leaf types in either a determinate or indeterminate genetic background (Tables 3 and 4). These data indicate that response to wilting differs in cucumber plants having different size leaves, and that wilting response to water stress is not necessarily indicative of plant tolerance to water stress in the reproductive stage.

A decreased transpiration rate in cucumber plants would be advantageous during brief water stress episodes. Data from this study suggest that stomata of genotypes which are homozygous $l l$ close when exposed to water stress. This hypothesis was supported by the fact that the degree and duration of wilting (Table 2) was less severe in genotypes homozygous $l l$ than in genotypes homozygous $L L$. Such a hypothesized reduction in leaf transpiration rates in $l l$ genotypes can lead to postharvest fruit disorders (Thomas and Staub, 1992). In our experiment, PFD in little leaf genotypes was always higher than in their normal leaf counterparts regardless of water stress or postharvest treatment. Thus, our results also support this hypothesis.

The normal leaf line $(L L D e D e)$ had significantly smaller seeds and cavity size than its little leaf counterpart in either a determinate or indeterminate background (Table 4). This indicates that seeds in little leaf lines mature more rapidly than those in the standard leaf size genotypes. Accelerated maturation in fruit of little leaf lines was also evidenced by the presence of larger seed cavities in these fruit. Both of these observations are indicative of a response to water stress imposed by low soil moisture levels leading to less acceptable fruit quality (Tables 3 and 4). In little leaf germplasm this response is manifested by more rapid senescence (i.e., fruit maturation) when compared to standard leaf size germplasm. Thus, stringent selection for slow seed maturation will be necessary when incorporating the $l$ allele into elite germplasm.

A determinate growth habit combined with multiple lateral branching has potential for increasing yield in once-over harvest operations (Serquen et al., 1997). Little leaf genotypes possess a multiple branching and sequential fruiting habit not present in standard leaf size genotypes. Thus, the branching and fruiting habit present in little leaf genotypes incorporated in a determinate habit has potential for increasing once-over yield in cucumber.

Optimizing yield in once-over harvest operations requires careful management of cultural practices to reduce plant stress. Development of determinate, multiple lateral little leaf genotypes for onceover harvest presents a problem for the breeder since the quality of fruit harvested from determinate genotypes (lldede) is likely to be lower than fruit from indeterminate genotypes when plants are subjected to water stress (Table 3). Moreover, although little leaf genotypes are more tolerant to water stress during the vegetative growth stage (i.e., no or less wilting) than their normal leaf counterparts (Table 2), little leaf genotypes are more susceptible to water stress in the reproductive stage (Table 5). Thus, incorporation of the $l$ allele into elite germplasm for adaptation to water stress will require rigorous selection during plant improvement. It appears that an evaluation of an array of genotypes differing in plant habit and leaf size will be necessary to identify multiple lateral branching genotypes most suitable for mechanical harvesting. Once identified, such genotypes will increase managerial flexibility of growers for controlling the frequency and severity of fruit quality disorders in growing areas where cucumber crops experience water stress.

\section{Literature Cited}

Barrs, H.D. 1968. Determination of water deficits in plant tissues, p. 53. In: T.T. Kozlowski (ed.). Water deficits and plant growth. vol. 1. Academic Press, New York.

Boyer, J.S. 1985. Water transport. Annu. Rev. Plant Physiol. 36:473516.

Cummins, T.L. and D.W. Krechtman. 1975. Relation of internal water to 
growth and development of the pickling cucumber. HortScience 10:319 (abstr.).

Holman, J.P. 1990. Heat transfer. McGraw Hill, New York.

Janoudi, A.K., I.E. Widders, and J.A. Flore. 1993. Water deficits and environmental factors affect photosynthesis in leaves of cucumber (Cucumis sativus). J. Amer. Soc. Hort. Sci. 118:366-370.

Johnson, J.R. 1991. Calcium nutrition and cultivar influence of tipburn of collard. HortScience 26:544-546.

Kirkham, H.B. 1985. Techniques for water-use measurement of crop plants. HortScience 20:993-1001.

Kramer, P.J. 1983. Water relations of plants. Academic Press, New York. Li, Y. and W.R. Gabelman. 1990. Inheritance of calcium use efficiency in tomatoes grown under low-calcium stress. J. Amer. Soc. Hort. Sci. 115:835-836.

Miller, D.E. 1986. Root systems in relation to stress tolerance. HortScience 21:963-970.

Navazio, J.P. and J.E. Staub. 1994. Effects of soil moisture and postharvest handling on pillowy fruit disorder in cucumber. J. Amer. Soc. Hort. Sci. 119:1234-1242.

Serce, S. 1997. The effect of plant habit and leaf size on water stress tolerance in cucumber (Cucumis sativus L.). MS thesis, Univ. Wis., Madison.
Serquen, F.C., J. Bacher, and J.E. Staub. 1997. Genetic analysis of yield components in cucumber (Cucumis sativus L.) at low plant density. J. Amer. Soc. Hort. Sci. 122:522-528.

Spomer, L.A. 1985. Techniques for measuring plant water. HortScience 20:1021-1027.

Staub, J.E., L.D. Knerr, and D.J. Hopen. 1992. Plant density and herbicides affect cucumber productivity. J. Amer. Soc. Hort. Sci. 117:48-53.

Staub, J.E. and J.P. Navazio. 1993. Temperature and humidity affect pillowy fruit disorder in cucumber. HortScience 28:822-823.

Staub, J.E. and C.E. Peterson. 1986. Comparisons between bacterial wilt resistance and susceptible gynoecious inbred cucumber lines, and $F_{1}$ progeny for yield and fruit quality. HortScience 21:1428-1430.

Staub, J.E., P. Rousos, and B.E. Struckmeyer. 1988. Anatomical characterization and possible role of calcium in "pillowy", a fruit disorder in processing cucumber. J. Amer. Soc. Hort. Sci. 113:905-909.

Steel, R. and J.H. Torrie. 1980. Principles and procedures of statistics. 2nd ed. McGrawHill, New York.

Thomas, R.S. and J.E. Staub. 1992. Water stress and storage environment affect pillowy fruit disorder in cucumber. J. Amer. Soc. Hort. Sci. 117:394-399.

Walter, W.M., Jr., D.G. Epley, and R.F. McFeeters. 1990. Effect of water stress on stored pickling cucumbers. J. Agr. Food Chem. 38:2185-2191. 